\title{
医用半導体レーザ装置の開発
}

\section{Laser Diode Pain Attenuater}

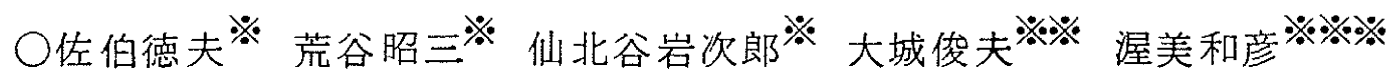

Norio Saeki ${ }^{*}$ Shozo Aratani ${ }^{\star}$ Iwajiro Sembokuya $※$

Toshio Oushiro $※$ Kazuhiko Atumi $※ ※ \%$

※松下電器産業桖光技術開発センター ※ ※日本医用レーザ研究所

※※東京大学医学部

Matsushita Electric Industrial Co : Ltd. Medical Laser Reseach Co: Ltd. ※※※ Tokyo University.

\section{A B S T R ACT}

A new laser diode pain attenuater was developed. Light power out put was increased to $60 \mathrm{~mW}(830 \mathrm{~nm})$ and resulted much more effective than the former type $(15-20 \mathrm{~mW}, 830 \mathrm{~nm})$.

Besides light weight and easy operati $(6.5 \mathrm{~kg} 440 / 350 / 150 \mathrm{~mm})$, the safety considerations were made such as skin tuch sencing switch, two kind of sound signals (pre-warning and waning), and red ligh signal (LED) for laser ir radiation, etc.

A basic study to clearify the mechanism of laser effect is now und erway.

\section{1. はじめに}

レーザ治療器として、CO $\mathrm{CO}_{2}$ レーザに代表される レーザメスが無血手術の可能性をはじめ、いくつ かの利点をもち医学会に貢献している。乙れは主 として熱勃果を利用したものであり、生体組織に レーザ光を照射、吸収させ、生体組織の凝固、切 開等を行なっている。

レーザそのあのが世に出て 20 数年の短かい歴 史の中にあって、各種の新しい素子・組合せを利
用した、レーザ治療器が開発されている。 てのような中にあって、化合物半導体技術を応 用して出てきたのが、半導体レーザである。 GaAsinP等を材料とした素子を使用した半導体レ 一ザが光ディスクメモリ、光通信に利用され、大 きな成果を納めつつある。

これらの成功の陰に完成品メ一カ上り高度な要 求が出され、それに応じて半導体レーザメ一カのの 日夜の努力によるもので、高信頼性、高出力、低 コスト化汇成功しつつある。

日本レーザー医学会誌 
これらの半導体レーザは他分野にますます利用 されていくであ万う。当然の結果として、医学分 野への応用が考えられている。

今回は非熱勃果を主体とした、半導体レーザ治 療器について述べる。

生体組織内の特に王痛点、東洋医学でいう径穴 等に数 $\mathrm{mW}$ 数 $10 \mathrm{~mW}$ のーザ光を照射するて とにより、疼痛を緩和するととができると云われ ている。ての考えに基ずき装置の開発を進めた。

開発に当り、レーザ光の強さの決定は、あち万 んのとと、光吸収は波長に依存することが大のた め半導体レーザの選択には十分配虑が必要である。 我々は次の条件のもとに半導体レーザを選び商品 化を進めた。

1) 高出力のとと

2）渗透性に富んでいるとと

3）量産性に富んでいること

4）信頼性の高いとと

以下半導体レーザの現況について図示した。

各種半体光源の発光波曼

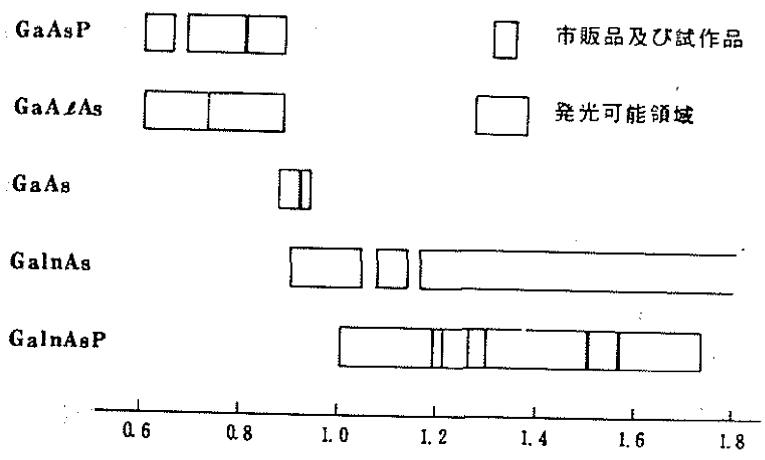

2. 本発明の径緯

本発明の動機は、アザ治療をレーザで行なって いたとき、併病であった疼痛が緩解したてとに端 を発する。レーザ治療は前述した如く、熱効果と 非熱効果の 2 つに大別される。乙の中にあって、 非熱効果を利用して、治療した文献が数多く発表 されている。

我々は前述の経験から、半導体レーザ治療器の 開発に取組んだ。サンプル完成の都度、臨床実験
を積み重ねた結果、前述同様、有効の結果を得る ことができた。

3. 装置の概要

本装置は本体部とプローブ部より成たっている。 (1) 本体部

・治療に供するプローブ部の半導体レーザの動 作条件の設定と制御

・照射時間をプリントアウトする機能、及び危 険防止機能が具備されている。

(2) プローブ部

・4 個の半導体レーザ、及びそれらの駆動回路 より構成されている。

\section{4. 仩様及び性能}

(1) 本体部
1） 寸 法 $440 \times 350 \times 150 \mathrm{~mm}^{3}$
2) 電 源……100 V、50/60 Hz
3）消費電力 $25 \mathrm{~W}$

となっている。 制御は全てマイコンで処理されていて、内容は
a) 照射時間 11 モート
$(5$ 秒 $\sim 180$ 秒)
b) パルス数
4 モート $(1 \sim 8 \mathrm{~Hz})$
c) パルスウ
4 モード(25\%〜連続)
d) 照射時間の累積とプリントアゥト

となっている。

尚本体部には 2 回路分が組込まれていて、同時 に2本のプローグを独立駆動するてとができる。 又使用勝手をよくするため、プローブ部の収納部 が用意されている。以下ブロック図と外観図を示 す。

本体ブロック図

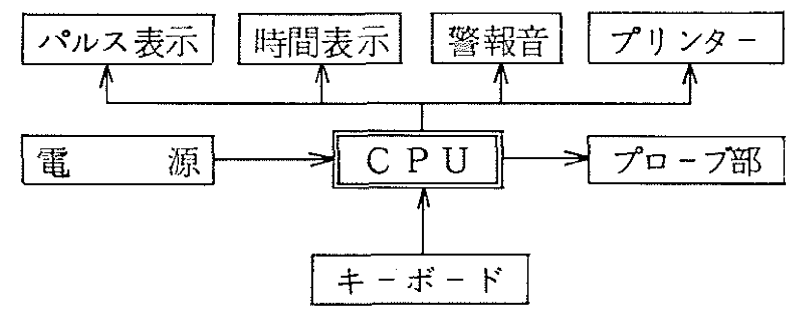


本体部外観㘡

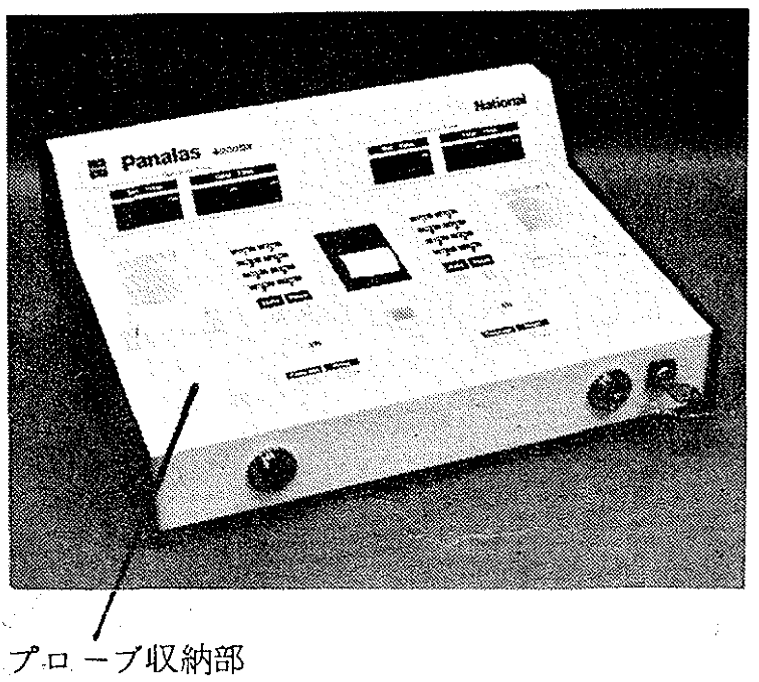

(2) プロープ部
1) 寸 法….. $44 \times 175 \times 30 \mathrm{~mm}^{3}$
2) 光出力 $. \cdots . .60 \mathrm{~mW}$
3）照射面積…... $2 \mathrm{~mm}^{2} \times 4$
4) 波 長 ……830 830

となっている。

安全確保のため、タッチセンサーが設けられて いる。こ机は治療部位に、プローブを押圼し、皮 皤の抵抗を測定するものである。数 $\mathrm{M} \Omega$ 以下と判 断されると、本体部に指示すると同特に、プロ一 プ上面の L E Dが点燈する。指示保従がい本体部 より事前にセットされたモードで、半導体レーザ 駆動回路を駆動し、レーザが照射される。以下外 観図とブロック図を示す。
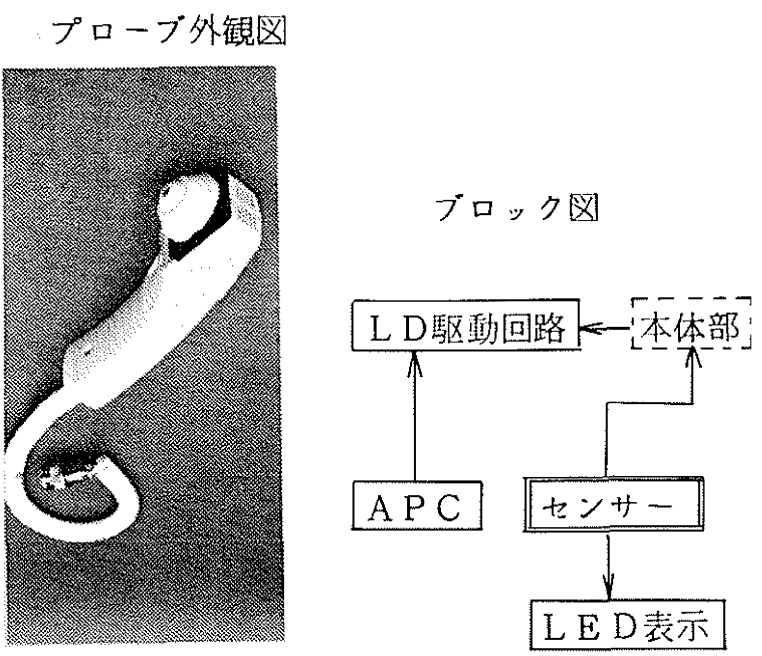

(3) 半導体レーザ

使用半埒体レーザについて、もう少し詳しく述 べる。

1）タイプ ……室温連続発振する GaAlAs

$$
\text { レーザダイオード }
$$

2) 光出力... $.25 \mathrm{~mW}(\mathrm{CW})$

3）動作電流 ……1 $25 \mathrm{~mA}$

4) Pinホトダイオード内蔵

となっている。以下外観図、チップ構造、及び代 表特性を示す。

\section{外観図}

苚位：的
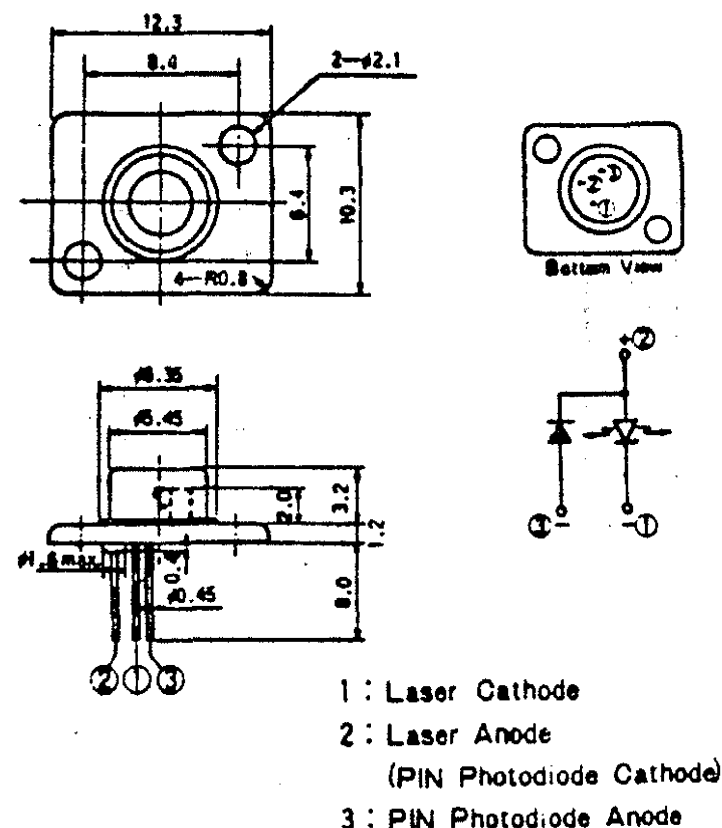

チップ構造

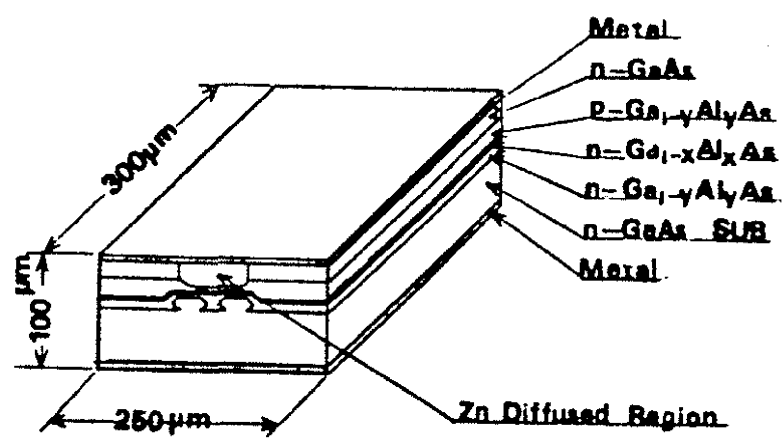




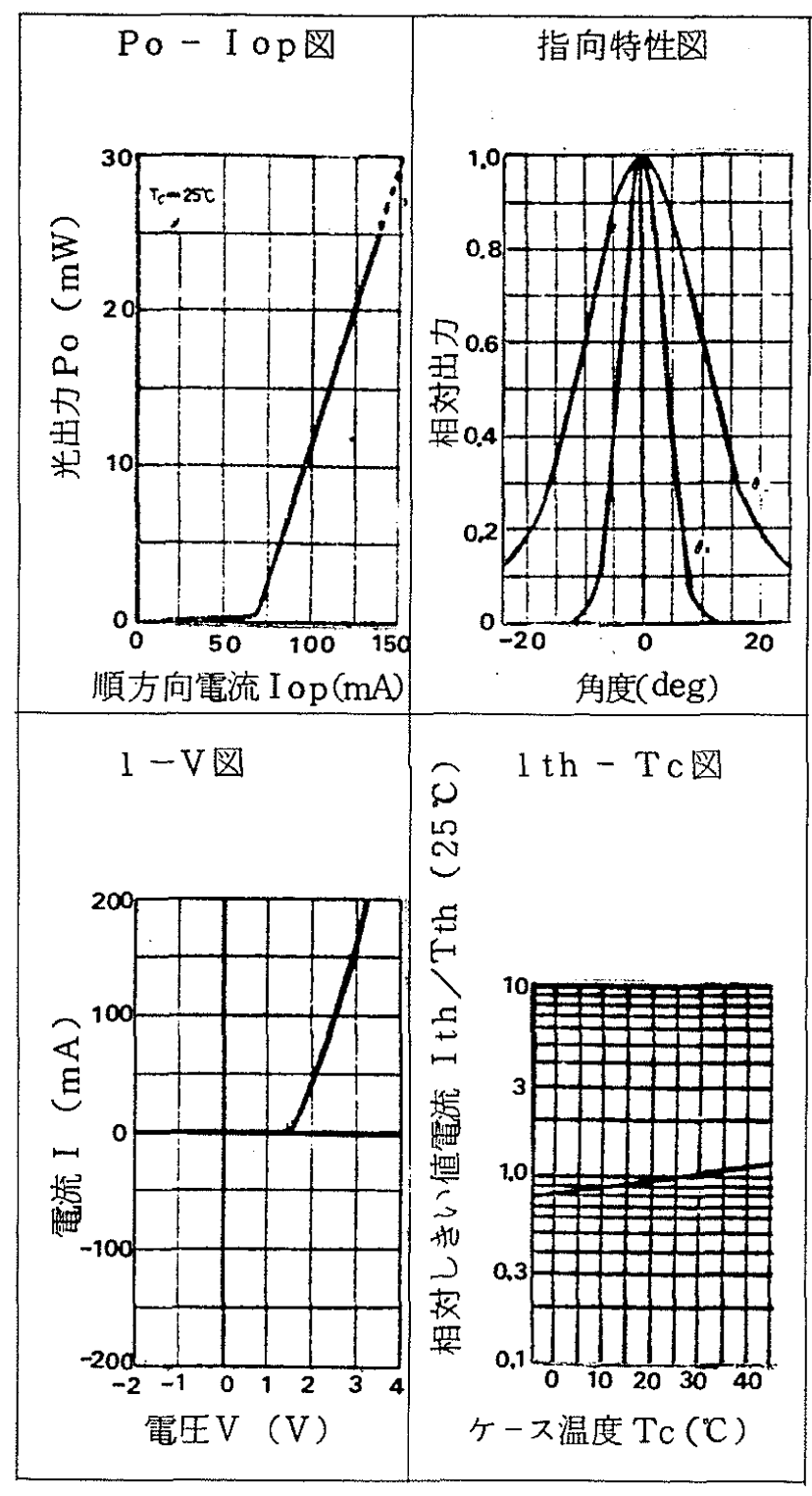

5. 特長

（1）小型・高出力（半導体レーザとして）

(2) 操作が簢単

(3) 安全性が高い

1) 光出力が数 $10 \mathrm{~mW}$ と小さく副作用がない。

2）眼球に対する安全性対策がなされている。

・治簝部位にプローブを押壬しないと動作し ない。

・レーザ照射前は響報音（A）を発する。

・レーザ照射中は警報音 (B) を発する。

・レーザ照射中はプローブ上面の L E Dが点

燈する。

・本体部にキースイッチが組込まれており、
使用者の限定と管理ができる。以下対策のポイン トを図示する。

安全対策ポイント図

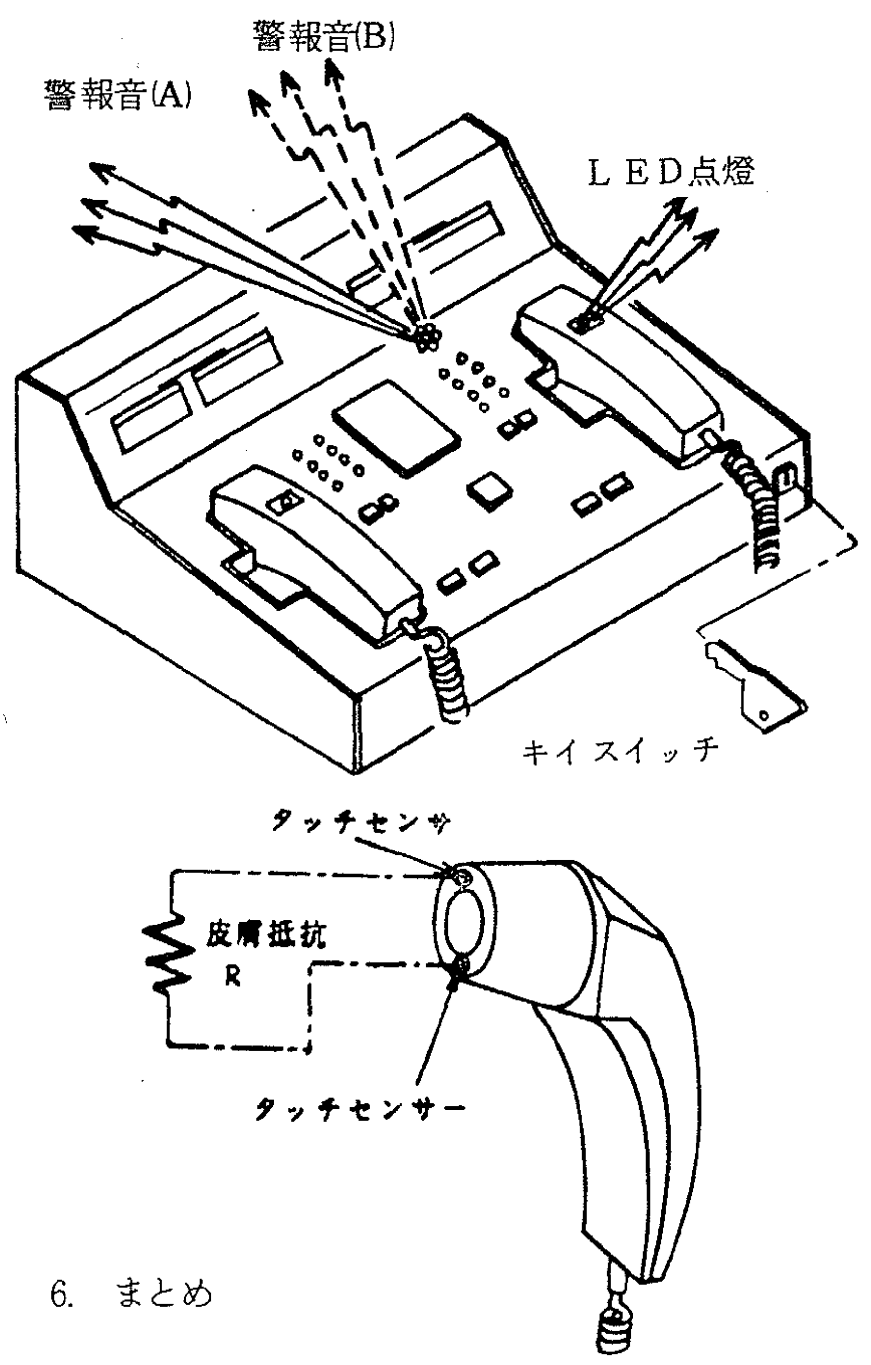

上記の如く本装置は安全性、操作性など、治療 用具としての機能を実現できた。現在病院、医学 施設で疼痛抑制効果の検討がなされている。

さらに作用機序等の把握のためにも

(1) 効果の客観的資料

（2）安全性確保のためのレーザ光出力の上限検討 などの臨床実験の積み重ねが必要である。 